\title{
POLITENESS IS DISTANCE - SERBIAN REQUESTS THROUGH THE MIRROR OF THE COGNITIVE SPEECH ACT SCENARIO MODEL
}

\author{
TATJANA ČIKARA ${ }^{1}$ \\ Milutin Milanković High Medical College of Vocational Studies, \\ Belgrade, Serbia
}

Cilj ovog rada predstavlja testiranje uspešnosti primene kognitivnog modela "scenarija” i teorije propozicionalnog idealizovanog kognitivnog modela u analizi značenja govornog čina zahteva u srpskom jeziku koji je u odnosu na druge žive jezike, bez obzira na široku zastupljenost govornog čina zahteva u pragmatičkim, sociolingvističkim i kognitivnim istraživanjima, ostao nedovoljno istražen. U okviru analize korpusa zasnovane na kognitivnom teorijskom modelu interpretacije značenja indirektnih govornih činova, tzv. „scenarija” analiziraju se i diskutuju odnosi blizine/udaljenosti između impliciranih komponenti scenarija, uz osvrt na pragmatičke efekte učtivosti ostvarene upotrebom određenih indirektnih jezičkih sredstava u kontekstima osetljivim na socio-kulturološke varijable distance, moći i težine zahteva. Kada je reč o fenomenu učtivosti, ustanovićemo na osnovu dominantnih komponenti "scenarija“ da li govornici srpskog jezika pokazuju tendencije ka „pozitivnoj” ili „negativnoj" učtivosti.

Ključne reči: indirektni govorni činovi, scenario, idealizovani kognitivni modeli, učtivost, govorni čin zahteva.

\section{INTRODUCTION}

The process of inference of meaning of Indirect Speech Acts (ISA ${ }^{2}$ ) has occupied the attention of language philosophers and linguists from the early pragmatic research work of Searle to contemporary 'relevance' and 'cognitive' theoretical studies. After a short review of the most prominent theories of inference and their influence on how

1 Kontakt podaci (Email): t.cikara@vmsmmilankovic.edu.rs

2 The abbreviation ISA will be applied throughout the paper for the sake of the space economy. 
ISAs are understood by cognitive linguistics, we explain the metonymic motivation of meaning interpretation of ISAs through the Model of Speech Act Scenario by Panther \& Thornburg (2004: 104). Finally, we elaborate on the Theory of Propositional Idealised Cognitive Models $\left(\mathrm{ICMs}^{3}\right)$ in order to determine if these models are applicable to the analysis of Serbian requests.

Within the analytical section, we discuss the distance relations between utterances and the 'core' components of speech act scenarios, thus reflecting the metaphor 'Politeness is Distance', which explains how the effect of politeness is achieved through greater conceptual distance from the central components. According to the most prevalent scenario components, we shall point out Serbian speakers' tendencies towards either 'positive' or 'negative politeness' (Brown \& Levinson 1987). The analysis is extended with the assessment of sociocultural variables of power, distance and ranking, which, according to Face Saving Theory, have a significant impact on the communicative event (Brown \& Levinson 1987). Finally, we shall critically observe the suitability of application of the two cognitive models with respect to both pragmatically conventionalised and non-conventionalised ISAs in the corpus of Serbian requests.

\section{FROM PRAGMATIC TO COGNITIVE APPROACHES TO THE INFERENCE OF MEANING OF ISAS}

The process of inference, that is, the process of recognition and identification of the speaker's communicative intention has been widely explored by pragmatically and cognitively oriented researchers.

For the proponents of pragmatics, led by Searle and Grice, inference was seen as a process of meaning interpretation based on the literally conveyed content and linguistic and extralinguistic context of the utterance. Grice went further to develop principles of rational cooperative linguistic behaviour subsumed under the Cooperative Principle, including four principal maxims, the caterpillars of inferential process, which refer to the truthfulness, informativeness, relevance and accuracy of the utterance - Maxim of Quality, Maxim of Quantity, Maxim of Relevance and Maxim of Manner (Horn 2005: 3-4).

On the other hand, relevance theorists, Sperber and Wilson(2005:3), define inference in terms of the Cognitive Principle of Relevance as a cognitive process operating in the interpretation of speech act meanings as spontaneous and automatic process, geared to the maximisation of the relevance of the propositional content, which combines with an appropriate set of contextual assumptions eventually leading to an intended conclusion.

Unlike the former theorists, contemporary linguists of cognitive orientation argue that these abstract principles of conversation and relevance are insufficient as descriptions of the pathways of meaning interpretation on the part of the interlocutors, and advocate an intermediate level of inferential principles - metonymies. Panther and Thornburg $(1998,2003,2004)$ regard metonymy as a mediating process in the determination of explicit meaning (explicature) and implicit meaning (implicature). Metonymic relations are manifested through contextually associated links between the

3 For the sake of economy the abbreviation ICM will be applied throughout the paper. 
source and the target meaning, that is, between ISAs and their direct counterparts. In order to understand the metonymic link the 'PART OF A SPEECH ACT FOR THE SPEECH ACT ITSELF' which underlies the speech act scenario (Panther \& Thornburg 2004: 104), we shall describe ISAs in terms of three mutually related cognitive perspectives construction grammar, speech act scenario and propositional ICM.

\section{INDIRECT SPEECH ACTS FROM THE COGNITIVE PERSPECTIVE}

In contrast with the Searlean and some modern cognitive approaches to indirect speech acts, including the Principle of Indirect Means (Frajzyngier \& Jirsa 2006: 513520) which put emphasis exclusively on the relation between the formal linguistic realisation and the illocutionary force of an act, the construction-based and scenariobased approach both define an ISA as a construction in terms of its unpredictable features and its metonymic links to its salient direct counterpart.

\subsection{Indirect Speech Acts from the Perspective of Construction Grammar}

The fundamental tenet of construction grammar defines construction as a formmeaning pair where certain aspects of form or meaning are not strictly predictable from the components of construction or from previously established constructions (Goldberg 2003: 219). Meaning is understood in its broadest sense, encompassing both semantically and pragmatically induced meanings. From the construction-based view, indirect speech acts, primarily conventionalised ones, are considered to have the status of a construction. Indirect speech acts of request such as Can you X?, take the form of questions, but are, in fact, uttered as requests. Therefore, following the principles of unpredictable properties, conventionalised speech acts are characterised by unpredictable illocutionary force and meaning if compared to their direct counterparts, which accounts for their status as constructions. Other unpredictable formal properties of indirect speech acts of request include the possibility of sentence-internal addition of request markers like please and kindly, conditional modals in constructions Will you X? Would you X?, expressing politeness rather than conditionality, and subordinate clauses stating the reason for the request in the preposition (Stefanowitsch 2003: 113-116).

Relying on unpredictable formal distinctions as defined within the constructionbased approach, the theory of speech act scenarios based on metonymic links explains the motivation of meaning interpretation of conventionalised indirect speech acts.

\subsection{Speech Act Scenario Model}

Taking ISAs as constructions with unpredictable properties into account, Panther and Thornburg $(1998,2003,2004)$ have developed a theory of ISAs as scenarios which essentially represent idealised cognitive models of certain culturally entrenched activities that include the event itself and knowledge about the preconditions and 
results of this event (schema of event). The scenario consists of four componential parts which partly correspond to Searle's felicity conditions. For example, the scenario of a speech act of request includes the following components - the BEFORE component which states preconditions and motivations for performing a request $\left(\mathrm{H}^{4}\right.$ can do $\mathrm{A}$ - background; $\mathrm{S}$ wants $\mathrm{H}$ to do $\mathrm{A}$ - motivation), the CORE component refers to the essential features of the request ( $\mathrm{S}$ puts $\mathrm{H}$ under a more or less strong obligation to do A), the RESULT component states the immediate pragmatic outcome of the felicitous performance of a request ( $\mathrm{H}$ is under an obligation to do $\mathrm{A})$, and the AFTER component describes the intended consequences of the realisation of the propositional content of the request $(\mathrm{H}$ will do A). Occasionally but not necessarily, when the realisation of the request evokes some emotional response in the speaker, such as gratitude, relief, etc., the AFTER subpart may be followed by another part, the CONSEQUENCES. The component arrangement within the scenario structure reflects conceptual distance from the CORE component, or among the components themselves. This connection with the CORE component is marked by three branches - the Presuppositional Branch, containing existential and ability presuppositions; the Motivational Branch, containing the speaker's wish for the realisation of the act and the Realisation Branch which refers to the satisfaction of conditions of the speech act, its realisation and the consequences (Panther \& Thornburg 2003: 130).

This abstract cognitive model can be combined with cognitive models of different events, depending on the situation and the specific content of the request. For instance, if $\mathrm{S}$ asks $\mathrm{H}$ to give him ${ }^{5}$ something, then both $\mathrm{S}$ and $\mathrm{H}$ need to share a 'GIVE schema' mutual knowledge about giving events and their participants, 'a giver', 'a recipient', and ' $a$ thing given'. This schema has to be integrated into the abstract scenario of a speech act of request (Stefanowitsch 2003: 117). The knowledge including presuppositions about the thing given - that it exists and that the giver has access to it, as well as that the recipient wants to have it, will be integrated with the BEFORE component. Knowledge about the act of giving will be incorporated into the CORE and the RESULT, while the consequences of such an act, the recipient having access to the thing given, will be subsumed under the AFTER component.

In spite of the complexity of the scenario which seems to embrace the whole linguistic and extralinguistic context, some authors claim that the scenario model fails to account for the pragmatic effects of politeness/impoliteness which particularly manifest themselves in indirect requests (Perez Hernandez and Ruiz de Mendosa 2002).

\subsection{Propositional ICM as a Reflection of Politeness Effects}

Perez Hernandez \& Ruiz de Mendosa (2002: 259-267) believe that several semantic features of indirect directives have been neglected by the approach based

4 Another set of abbreviations will be included in both the theoretical and analytical part: $\mathrm{H}$ (Hearer), S (Speaker), and $A$ (Act).

5 Since the gender of the participants in the communicative events is not relevant to the analysis at hand, we shall treat both the speaker and the hearer as of masculine gender for the sake of clarity and coherence, except for the cases in the analytical section where it is evident from the verb form in the example that the speaker is 'she'. 
entirely and exclusively on speech act scenarios. These two authors suggest that the scenarios should be elaborated and integrated into a more general type of knowledge organisation structure, the so-called propositional ICMs (Perez Hernandez and Ruiz de Mendosa 2002: 264).

The propositional ICM is supposed to include the parameters - cost-benefit, as an assessment of the cost and/or benefit that the action A involves for the speaker and/ or the hearer; optionality, as an assessment of the degree of optionality conveyed by a speech act, that is, the degree to which the speech act restricts the addressee's freedom to decide whether or not to carry out the requested action, and power, as an assessment of the power relationship that needs to hold between the speakers in order to be able to perform a speech act. The ICM of a request includes the following components as well: the act represents a cost to the hearer and a benefit to the speaker; high optionality implying politeness and the power relation between the interlocutors is considered immaterial (Perez Hernandez and Ruiz de Mendosa 2002: 264).

The aim of this article is to verify the application of the cognitive theory encompassing a speech act scenario, an event schema and a propositional ICM as a conceptual tool for interpreting ISAs of requests with a view to the politeness effects produced by the conceptual distance between the components of the scenario and the mutual impact of sociocultural variables within a communicative event.

\section{METHODOLOGY}

The examples were collected by means of a Discourse Completion Test (DCT) completed by 70 adult native speakers of Serbian, among whom $84 \%$ have a university degree and $16 \%$ a high school diploma. The average age of the respondents is 35 . We have chosen this method regardless of its alleged downsides, related to artificial language production, because it provides sufficient diversity of instances susceptible to analysis, particularly in terms of politeness effects.

The test was designed to investigate the role of social variables in the request formulation, the request being directly intertwined with pragmatic notions of face and politeness (Brown \& Levinson 1987). It is important to emphasise that a special distinction has been made between two types of requests - those requiring an action on the part of the hearer and therefore a change in the denotative referent space, and the requests for information underlain by the identification of the referent on the part of the hearer who is expected to provide a verbal act (Popović 2005: 994).

Taking the formerly mentioned issues into consideration, the test consists of six situations typical of Serbian culture and social practice, each of which implies a particular social variable or different linguistic medium. Moreover, it is essential to point out that our interests do not spread beyond the qualitative analysis of the formal and semantic properties of the requests according to the speech act scenario. However, since the scenario model fails to account for the particular politeness effects produced by the linguistic content of certain utterances, those utterances will be analysed within the propositional ICM model. 


\section{ANALYSIS OF THE SCENARIO COMPONENTS OF THE SPEECH ACT OF A REQUEST}

In this section of the article, we are going to analyse various examples of the speech act of a request by means of identifying the components of the scenario and pointing out its conceptual distance from the CORE component, thus reflecting the prototypical nature of the request itself and the metonymic link 'PART OF A SPEECH ACT FOR THE SPEECH ACT ITSELF'. We are going to explain the situations which served as social contexts for realisation of the speech act of a request, including some formal features of Serbian requests and their tendencies to be qualified as 'positive' or 'negative' politeness as well.

\section{Situation 1: Supermarket}

The first situation is located in a supermarket where the speaker is a customer complaining to the shop assistant about the quality of the goods she ${ }^{6}$ has bought and demanding either her money back or replacement of the piece of meat she has bought.

The following linguistic manifestations of the request have been identified in Serbian:

(1) Ovaj komad mesa je pokvaren, želim da mi vratite novac.

(2) Ovo meso je pokvareno i volela bih da mi vratite novac.

(3) Hoću svoj novac nazad.

(4) Zahtevam da mi vratite novac!

(5) Vratite mi novac!

(6) Ili ćete mi vratiti novac, ili ćete mi dati novo meso!

(7) Prijaviću vas inspekciji ako ne vratite novac!

In the situation where S's face is at risk, the variable of power, more precisely, the status of $S$ is stressed in a way that $S$ considers herself of somewhat higher status than $\mathrm{H}$, thus possessing a legitimate right to issue a request. The request proper would be formulated directly as an imperative -Vratite mi novac, implicating the CORE component.

The examples (1) to (5) from DCT show certain tendencies of Serbian speakers towards expressing their desire for $\mathrm{H}$ to perform the act by means of performative and modal constructions with mandative meanings, involving the verbs zahtevati, voleti, želeti or hteti. Therefore, the CORE component has been evoked, suggesting the preference of Serbian speakers towards direct means of address, thus supporting the hypothesis of a higher level of directness among Eastern and South-Eastern speech communities (Ogiermann 2009), as opposed to the Western, Anglo-American communities oriented towards a higher degree of indirectness and negative politeness

6 In addition to the masculine gender pronouns, the feminine gender pronouns will be used to refer to the speaker only in those situations in the analytical section where the verb form in the example suggests that the speaker is 'she', as in the situations 1 and 6 in (2) and (36). 
(Brown \& Levinson 1987; Trbojević 2009). In addition, the RESULT component is usually evoked through illocutionary acts of threat, as in examples (6) and (7), putting $\mathrm{H}$ under a strong degree of obligation to perform the act.

\section{Situation 2: Party in the neighbourhood}

The second situation has to do with a party organised by $\mathrm{H}$, and the inconveniences it causes to $S$, that is, $S$ 's negative face - a desire for autonomy and freedom of action (Brown \& Levinson 1987: 13). S's task is to ask a neighbour to turn down the music. The alternatives for setting such a request are the following:

(8) Komšija, molim vas, jako sam umorna, ako biste mi izašli u susreti utišali muziku?

(9) Molim vas, utišajte muziku i lepo se provedite!

(10) Izvinite, morao bih da Vas zamolim da smanjite jačinu zvuka muzike, jer imam važan razlog.

(11) Ja bih vas zamolila da utišate muziku, jer ujutru rano idem na put.

(12) Komšija, molim vas da malo stišate muziku.

(13) Ako ne utišate muziku u narednih nekoliko minuta, obratiću se policiji.

Only example (8) evokes the BEFORE component, pointing to the Presuppositional branch of the scenario about the hearer's ability and willingness to perform the action. The great majority of examples (9) to (12) actually evoke the CORE component, suggesting Serbian preferences to more direct utterances. The choice of lexical means in (9) and (12) includes an imperative form accompanied by the lexical-semantic performative formula of the verb moliti, which serves as a down-toner of illocutionary force (Popović 2005: 1022). However, examples (10) and (11) contain modalised constructions consisting of modal and performative verbs in the potential form which, in the context of politeness, transforms its semantic meaning of epistemic distance - the degree of S's commitment to the realisation of the proposition - into a pragmatic one (Trbojević 2004: 2009). Due to its conceptual distance from the core, imperative meaning, the constructions containing potential can be marked as highly polite and indirect.

The RESULT component has been realised by means of a threat, pointing to Serbian speakers' orientation to the preferred form of directness in cases where the participants in the communicative event are of equal status.

\section{Situation 3: Asking someone to act as guarantor for a loan}

The third situation emphasises the request itself, its strength and high ranking of imposition. The variables of power and distance are eliminated, in that $\mathrm{S}$ and $\mathrm{H}$ are close friends, but $\mathrm{S}$ has to ask $\mathrm{H}$ to be his endorser - a request involving a high degree of imposition.

The realisation of this type of request evokes the BEFORE and the CORE component: 
(14) Hoćeš li da mi budešžirant?

(15) Da li bi možda hteo da mi budeš žirant?

(16) Je'I nije problem da te zamolim za uslugu?

(17) Možeš li, molim te, da mi budeš žirant?

(18) Da li bi mogao da mi budeš žirant?

(19) Da li si u mogućnosti da mi budeš žirant?

(20) Druže moj, potreban mi je žirant za kredit.

(21) Da li pristaješ da mi budeš žirant?

(22) E, 'aj budi mi žirant! Znam da hoćě̌.

(23) Molim te da mi budešžirant.

In this type of situation, where both $\mathrm{S}$ and $\mathrm{H}$ are of the same or similar social status, the two of them being friends, the ranking of imposition of the request is the crucial determining factor in the choice of formal linguistic means. The most frequently occurring constructions include modal verbs denoting presuppositions about S's willingness or ability to perform the act, thus evoking the BEFORE component $(14,15$, $17,18)$. In addition, the interrogative form of examples (15) and (18), accompanied by the form of potential denoting capacity and willingness, contributes to high optionality, thus allowing $\mathrm{S}$ to communicate the fact that $\mathrm{H}$ 's freedom of action is not undermined by the speech act (Perez Hernandez \& Ruiz de Mendoza 2002: 262).

Due to the high level of imposition of the request, the associations to the CORE are likely to be avoided, suggesting a greater degree of indirectness and 'negative' politeness.

\section{Situation 4: At the workplace}

The fourth situation puts the social variable of distance between $\mathrm{S}$ and $\mathrm{H}$ in the forefront, the two of them being of the same status, but without familiarity in their social relationship. $S$ has to ask his colleague for help, thus reflecting the 'request for action' type. The following utterances were realised:

(24) Da li biste mogli da mi pomognete?

(25) Imaš li vremena da mi pomogneš?

(26) Jesi li raspoložena da mi pomogneš?

(27) Izvini, da li bi ti bio problem da mi pomogneš oko posla koji moram da završim do kraja radnog vremena?

(28) Plašim se da neću stići da završim ovo do kraja dana. Da li bi mogla malo da mi pomogneš?

(29) Hoćeš li da mi pomogneš da završim ovo, pa da idemo posle na kafu?

(30) Kolega, izvini, malo mi je neprijatno, ali moram da te zamolim da mi pomogneš.

The request is performed by evoking the BEFORE component, most frequently by means of the modal verb MOĆI denoting ability and the potential form suggesting conceptual distance from the 'core' directive meaning, (24), (27) and (28). The CORE is 
evoked by S's justification of necessity for making the request. The AFTER is implicated by an expression of promise on the part of $S$ in example (29), thus pointing to the Realisation branch implying $S$ 's consequent emotional response in the form of gratitude. Judging by the prevalence of the BEFORE component, we may observe the prominence of conventionally-indirect speech acts and, consequently, 'negative' politeness.

\section{Situation 5: Addressing the desk clerk at the bus/train station or the airport}

The fifth situation represents the 'request for information' type, where $S$ is likely to consider himself higher in social rank than $\mathrm{H}$ who works as a clerk at the bus/train station or airport. $S$ wants to know the time of his bus/train/flight. The requests were formulated as:

(31) Izvinite, da li biste mi rekli kada polazi voz za Novi Sad?

(32) Da li možete da mi kažete vreme polaska voza?

(33) Izvinite,potrebna mi je informacija o polasku voza za Užice.

It is evident that solely the BEFORE component is evoked in this type of situation. The lack of utterance diversity might be caused by the formality and social typicallity of the situation which requires a kind of formulaic linguistic behaviour regardless of social variables.

\section{Situation 6: Sending an e-mail message}

Finally, the sixth situation represents the same type of request, but in a different linguistic medium, the written form. $S$ is supposed to enquire, by means of an e-mail, about the conditions of payment of her package tour and the possibility of paying in instalments.

(34) Da li biste mogli da mi date informaciju da li postoji mogućnost plaćanja na rate i koji su uslovi?

(35) Da li biste bili u mogućnosti da mi odgovorite na mejl u vezi sa mogućnosšću plaćanja na rate?

(36) Sobzirom da nisam uspela da na Vašem sajtu pronađem informaciju vezanu za plaćanje na rate, molim Vas da mi odgovorite na sledeća pitanja...

In examples (34) and (35) the BEFORE component is evoked metonymically through expressions of H's ability to supply S's need for information and S's wish/need to acquire the necessary information, denoted by a highly polite potential form. The CORE is evoked through the use of performative formulas including lexical verbs moliti/zamoliti.

On the whole, it can be concluded that the effect of politeness and conceptual distance in Serbian is achieved by the use of the potential form which can vary according to the degree of politeness implied. In other words, the potential itself 
refers to a hypothetical state of affairs, thus bringing about the meaning of distance between the real and the desired state of affairs. If, however, this form is combined with the modal verbs MOĆI or HTETI, the degree of both distance and politeness may be considered higher, as demonstrated by examples (15), (18), (24), (28) and (34) if compared to examples containing potential forms of ordinary lexical verbs, as in (2), (8), (27), (31) and (35). The same accounts for the performative formulas, the implicitness and indirectness of which increase if performative verbs are used in potential form.

However, the scenario approach within an ICM proves inadequate to account for non-conventionalised speech act realisations, including threats (6), (7), (13) and hints expressed by impersonal constructions without the subject in the initial position denoting necessity and desiderative meanings (Piper 2005: 638-644) as in example (33), due to their high dependency on the context of the situation. Most of these expressions, according to the cited authors, are characterised by the greatest conceptual distance from the CORE component, thus having indexical functions, although Panther \& Thornburg (1998: 759) do not deny their potential for metonymic interpretation within an adequate context.

\section{CONCLUSION}

When it comes to the process of inference and meaning interpretation of ISAs, Panther \& Thornburg's approach $(1998,2003,2004)$ has unequivocally enhanced the theories of John Searle and relevance theorists in that it highlights the underlying mechanisms of human reasoning based on metaphoric and metonymic networks established in our minds during the process of inference. Likewise, it reveals the speakers' general tendencies to formulate utterances evoking presuppositions and motivation for the performance of the request reflected in the BEFORE component, thus leading the addressee towards the indirectly conveyed meaning interpretation by establishing metonymic links with conceptually contiguous direct speech acts. The prevalence of conventionally-indirect requests suggests the speakers' tendencies towards 'negative' politeness characterised by distance and respect in situations of high risk or high interest to the speaker's face, regardless of the activated social variable. Thus, we cannot speak of a strict division into 'positive' or 'negative' politeness orientation among speech communities.

Despite the above mentioned advantages, the theory incorporating a cognitive model of scenario and a propositional idealised cognitive model fails to account for non-conventionalised speech acts, the production of which should, by no means be neglected. Neither does this theory show the pathways of the speakers' understanding of contextual factors in making their choice in the linguistic formulation of the request.

Therefore, future studies based on cognitive approaches to speech acts might incorporate certain holistic questionnaires of evaluative type, reflecting the speakers' patterns of thinking, their linguistic choice and their assessment of the communicative event upon formulating and interpreting a particular speech act. 


\section{REFERENCES}

Brown, P. \& S. Levinson. 1987. Politeness: Some universals in language usage. Cambridge: CUP.

Frajzyngier, Z. \& B. Jirsa. 2006. The Principle of Indirect Means in language use and language structure. Journal of Pragmatics 38, 513-542.

Goldberg, E. A. 2003. Constructions: a new theoretical approach to language. TRENDS in Cognitive Sciences 7/5, 219-224.

Horn, L. R. 2005. Implicature. The Handbook of Pragmatics. In L. R. Horn and G. Ward (eds.). [Internet]. Available at: http://www.blackwellreference.com/subscriber/ tocnode? id=g9780631225485_chunk_g97806312254853 [17.10.2012].

Ogiermann, E. 2009. Politeness and indirectness across cultures: A comparison of English, German, Polish and Russian requests. Journal of Politeness Research 5, 189-216.

Panther, K-U. \& L. Thornburg. 1998. A cognitive approach to inferencing in conversation. Journal of Pragmatics 30, 755-769.

Panther, K-U. \& L. Thornburg. 2003. Introduction: On the conceptual nature of metonymy. In K.-U. Panther and L. Thornburg (eds.) Metonymy and Pragmatic Inferencing. Amsterdam and Philadelphia: John Benjamins, 1-19.

Panther, K-U. \& L. Thornburg. 2004. The role of conceptual metonymy in meaning construction. [Internet]. Available at: http://www.metaphorik.de/06/ pantherthornburg.htm [02.09.2012].

Perez Hernandez, L. \& F. J. Ruiz de Mendoza. 2002. Grounding, semantic motivation, and conceptual interaction in indirect directive speech acts. Journal of Pragmatics 34, 259-284.

Piper, P. 2005. Semantičke kategorije u prostoj rečenici: sintaksička semantika. U M. Ivić (ur.) Sintaksa savremenog srpskog jezika, Prosta rečenica. Beograd: Institut za srpski jezik SANU/Beogradska knjiga/Matica Srpska, 575-982.

Popović, Lj. 2005. Komunikativne funkcije proste rečenice. U M. Ivić (ur.) Sintaksa savremenog srpskog jezika, Prosta rečenica. Beograd: Institut za srpski jezik SANU/ Beogradska knjiga/Matica Srpska, 983-1060.

Stefanowitsch, A. 2003. A construction-based approach to indirect speech acts. In K.-U. Panther and L. Thornburg (eds.) Metonymy and Pragmatic Inferencing. Amsterdam and Philadelphia: John Benjamins. [Internet].Available at: http://www-user.unibremen.de/ anatol/docs/ms_isa.pdf [10.09.2012].

Trbojević, I. 2004. Modalnost, sud, iskaz: epistemička modalnost u engleskom i srpskom jeziku. Beograd: Filološki fakultet.

Trbojević, I. 2009. Some contrasts in politeness structure of English and Serbian. In M. Kuzniak \& B. Rozwadowska (eds.) PASE Papers 2008: Studies in Language and Methodology of Teaching Foreign Languages. Wroclaw: Oficyna Wydawnicza ATUT, 177-184.

Wilson, D. \& D. Sperber. 2005. Relevance Theory. The Handbook of Pragmatics. Horn, L. R. and G. Ward (eds.). [Internet]. Available at: http://www.blackwellreference. com/subscriber/tocnode?id=g9780631225485_chunk_g978063122548529 [17.10.2012]. 


\section{SUMMARY}

\section{POLITENESS IS DISTANCE - SERBIAN REQUESTS THROUGH THE MIRROR OF THE COGNITIVE SPEECH ACT SCENARIO MODEL}

Our analysis was based on the theoretical model of speech act scenarios proposed by Panther \& Thornburg $(1998,2003,2004)$. We identified the components of the scenario in Serbian requests, showing that speakers most frequently resort to the BEFORE component in formulations of indirect requests implying the ability/capacity and willingness of the hearer to perform the act, with only sporadic instances of the RESULT and AFTER components. When it comes to the CORE component, our results show that Serbian possesses various linguistic means to express direct requests, in the first place by performative formulas, apart from the imperative proper. Further on, we make a synthesis of the two principal approaches within cognitive linguistics, the scenario approach and the propositional ICM approach, in order to account for the politeness effects produced by the mutual influence of sociocultural variables and the linguistic content of the utterance. Also, we observed certain inconsistencies in the application of the cognitive models, particularly in the domain of non-conventionalised indirect speech acts.

KEYWORDS: indirect speech acts, scenario, idealised cognitive models, politeness, speech act of request.

(Original scientific paper received 23.01.2013;

revised 22.09.2013;

accepted 18.10.2013) 